\title{
3
}

\section{A Relational Database to Understand Social Innovation and Its Impact on Social Transformation}

\author{
Marie J. Bouchard, Catherine Trudelle, Louise Briand, Juan-Luis \\ Klein, Benoît Lévesque, David Longtin and Mathieu Pelletier
}

\section{Introduction}

Research on social innovation has, to date, mainly been carried out through case studies. This is due to the unique character of innovations, at least when they emerge, and the fact that the concept of social innovation is still poorly codified. Case studies are typically used to explore new research areas for which existing theory seems inadequate. A case study approach is the prescribed methodology to explore phenomena that are not easily distinguishable from their context and to document them thoroughly by referring to multiple information sources (Yin, 1994).

A cross-analysis of many case studies can shed light on the links between different forms of social innovation and their configurations, evolution and distribution in time and space. However, the ultimate value of such an analysis is quickly exhausted due to the limited amount of information that can be processed in a qualitative way. Moreover, cross-analyses are likely to fail to establish links between much of the data from case studies, which impedes knowledge building.

These observations prompted a team of researchers from the Centre de Recherche sur les Innovations Sociales (CRISES) to build a data warehouse - the CRISES Database on Social Innovations - dedicated to the analysis of data that has so far been limited to the case method. The working hypothesis is that a quantitative analysis of a large number of cases will reveal aspects of social innovation that have not previously been observed while also generating information on the relationship between social innovation and social transformation. The CRISES Database on Social Innovations initially focuses on an existing body 
of research on social innovation that was produced in the province of Québec (Canada). However, the goal is eventually to expand the work to include other provinces and countries. To allow for this type of research, which requires multivariate statistical analyses of a large volume of information, the data warehouse must be able to offer flexible data storage options.

This chapter discusses the different stages of building a data warehouse based on case studies $(n \geq 500)$ on social innovations, in particular those emerging from the social economy, conducted in Québec over a period of over twenty years (1986 to 2011). With a focus on the methodological, theoretical and epistemological challenges of such an undertaking, this chapter also discusses the potential scientific contribution that such an initiative will provide to the study of social innovation and social transformation. Beyond the work of CRISES, this project will provide the research community with a conceptual thesaurus on social innovation and a relational database model to analyse case studies, facilitating inter-regional comparison. This new way of gathering data will reinforce the capacity to develop theories about social innovations.

\section{The formalisation of a research field}

Social innovation is often the product of improvisation, serendipity and tacit knowledge acquired through experience (Bouchard, 1999). In addition, most social innovations are often not labelled as such. In that context, one of the primary functions of research is to identify and recognise these innovations, referred to as codification and formalisation. For this task, the preferred methodology of CRISES researchers has been based, since the founding of the Centre in 1986, on case studies. It has also tended to be the main methodology of other large social innovation research projects, such as several of those funded by the European Commission's Seventh Framework Programme. ${ }^{1}$

Nevertheless, the case study methodology has certain limitations. First, case studies seek to understand a particular phenomenon occurring in a given context. In epistemological terms, this means that they generally follow an idiographic rather than nomographic perspective. ${ }^{2}$ Such an approach helps to understand the meaning of a specific phenomenon but is not intended to establish evidence on - or formulate general and causal laws about - an object under study. For this reason, this methodology does not lend itself to the generalisation of knowledge. Secondly, works conducted in a multidisciplinary research centre such as CRISES reflect a diverse range of interests and theoretical stances 
(Tardif, 2005). This calls for the formalisation and systematisation of the research results in order to advance knowledge.

As a relational database compiled of source material from case studies, the CRISES Database on Social Innovations aims to serve as a complementary tool for creating new research opportunities and for overcoming these limitations, at least in part. A database is a collection of data that is structured in a certain way. A database model determines that structure. The most commonly used database models include the hierarchical, network, object and relational models. The CRISES Database on Social Innovations is based on the relational model. A relational database is a database that stores information both about the data and how it is related. It enables data to be structured in a way that formalises the logical relations, or interdependencies, between the data. Queries can be made to the relational database, which would enable associating data in a number of ways, unlike a flat database that only offers a single table, with a determined relation between the rows and the columns.

The creation of a relational database proceeds in three stages of modelling: conceptual, logical and physical. The first stage, laying the foundation of the overall process, is the creation of the conceptual model, or schema, for the formal and systematic organisation of data. ${ }^{3}$ It also involves the defining of entities, or core concepts, used to describe phenomena related to social innovation. In the subsequent stage of creating the logical model, these entities are then operationalised through a series of attributes, in turn allowing for the retrieval of data from the case studies and for them to be organised on the basis of logical links and relationships. The third stage consists of the actual programming of the database into a physical model.

The creation of a relational database is an iterative process in which changes made at a later stage, such as during the development of the logical model, may lead to a revision of work done at an earlier stage, such as during the building of the conceptual model (Mata-Toledo and Cushman, 2002, p. 257). In the case of CRISES, the conceptual modelling led to the creation of a code book compiling some fifty-nine entities of three to fourteen attributes each, all of which are linked together through relations. In fact, relations underpin the basic concept of the relational model and represent the association of elements from the real world. The logical relations or links are based on relational algebra and allow detailed mathematical calculations to be performed.

The CRISES Database on Social Innovations is based on case studies that have already been conducted, so the design methodology differs slightly from the process described above in that the conceptual model 
was deduced from theory in addition to being induced from empirical data. Many steps mark the process of building the relational database on social innovations.

The formalisation allows for the transformation of qualitative data, which is textual in the case studies, into quantifiable data (i.e., nominal, ordinal, interval or ratio) that can then be subjected to statistical analyses. For example at CRISES, trained researchers have to go through and code each case study using the conceptual thesaurus on social innovation. Thus, the database can perform multidimensional comparative analyses on social innovation using both descriptive and explanatory statistical methods. For the corpus of existing case studies, the codification process occurs a posteriori but will in the future be implanted a priori, in the case study research design. In this sense, this project will impact future case study research on social innovation at CRISES, and potentially that of other researchers who adopt a similar view.

The CRISES Database on Social Innovations will enable the measurement of innovation from three spatial-temporal components, namely location, time and theme (Sinton, 1978). To study a phenomenon, one of these components is fixed, the second is varied in a controlled manner and the third is measured. Given the structural framework of the data, the relational data model allows for quantitative analyses that can capture all of these types of profiles to be performed. Multidimensional comparative analysis opens up the possibility of studying social innovation in a systematic way and to spot or confirm trends that were difficult to identify using the case study method. However, the results generated by this systematic quantitative analysis may also be counterintuitive or run counter to prevailing ideas in the field of social innovation and social transformation.

\section{The challenges of database design}

Given the nature of the sources - namely case studies based on nonprobabilistic sampling and not designed for integration into a database a hybrid approach that was both inductive and deductive was adopted to identify, define and operationalise the key concepts relevant to the study of social innovation. This approach made it possible to base the conceptual model on theories mobilised in the framework of CRISES research $^{4}$ (deductive approach) and to delimit the data that was effectively provided by the case studies (inductive approach).

This approach raised the challenge of building, a posteriori, a coherent conceptual model. Despite their convergence and complementarity, the 
conceptual tools used in CRISES studies had not been fully integrated into a common framework (Tardif, 2005). Building the conceptual model of the database thus strengthened this theoretical integration. Building the conceptual model prompted CRISES researchers to reflect more deeply on notions they had used in previous research and to address points of divergence between different approaches. Nevertheless, many challenges remained with regard to the definition of concepts and their operationalisation using attributes allowing the retrieval and correlation of data from case studies.

One of the difficulties was the polysemic nature of certain concepts that had more than one meaning (e.g., market can mean an actual place where goods are sold, and it can also mean a group of consumers for an organisation's products, or the meeting of the offer and demand forces within the economy). The meaning of concepts also can depend on context (e.g., democratic control has a different significance in a consumers' cooperative than is has in the workplace or in the public sphere). Some concepts, such as social innovation or social economy, still have an open-ended theoretical basis. Research has also advanced conceptually, such as by developing the notion of regressive social innovation, which emerged more recently in some CRISES work (Hodgson and Briand, 2013). Other concepts have multiple theoretical anchor points, such as the concept of governance, used in the standard economic and financial approaches as well as in institutional sociology and social geography. Here as well, more recent studies have contributed different meanings of the concept (Cornforth, 2004; Bernier, Bouchard and Lévesque, 2002). One impact of building a relational database was the clarification of the scope and limits of the conceptual field of CRISES. In the process, the conceptual approach to social innovation at CRISES became more rigorous and in depth (Bélanger and Lévesque, 1992; Favreau and Lévesque 1995; Favreau, 1995; Lapointe 2000a; 2000b; Comeau et al., 2001; Klein and Champagne, 2011; Bouchard and Lévesque, 2013).

Concepts associated with social innovation are diverse, ranging from collective action to public policy, beliefs and cognitive scheme, interorganisational relationships, and many more. A further task concerned determining the relationships between concepts such that these are clear and unambiguous. Here, some concepts may have some degree of redundancy, albeit without lending themselves to be classified into categories and subcategories. For example, the concept of partnership could be synonymous with the concept of network in the case of public policy networks that involve the participation of civil society organisations in 
the delivery or co-production of services (White et al., 1992). However, partnership may also be conceived of as a system of governance for a territory or sector that engages government and non-governmental actors in the co-design and co-construction of public policies, or alternatively as hierarchical, community-based, corporate or competitive types of governance systems (Enjolras, 2008). Some concepts may also appear as sub-categories of more than one concept (or category). Thus, a network might be a form of organisation (e.g., the Desjardins Movement, a large cooperative federation) or a form of governance (distributed power networks). Choices must, therefore, be made such that the conceptual model permits a continuous and coherent analysis of the data without a critical loss of their analytical significance.

Finally, each of the categories used in codifying data must be described with attributes that are sufficiently accurate to be unambiguously identifiable in the data, as well as mutually exclusive so that their classification is done uniformly, irrespective of the person who did the codifying. This requires specifying the concrete factual and observable dimensions of the mobilised concepts rather than attributing them to a single concept. For example, when codifying 'triggers of social innovation', a researcher may choose to group problems that were perceived or experienced at a collective level (e.g., decay of a territory or the high school dropout rate) into the 'problems' category; problems experienced by people (such as need for housing or employment) into the 'needs' category; and wishes for change at the values scale (such as selfmanagement), self-realisation (empowerment) or social demands (e.g., justice or fairness) into the 'aspiration' category. These choices must be coherent throughout the operationalisation of the database and comply with the principle of relevance, calling for coherence with the original nature of the material analysed, from the case studies. Training the researchers on the codification manual and asking different researchers to codify the same text in order to reach interrater agreement helped to ensure consistency.

While the work of creating the CRISES Database on Social Innovation is not yet completed, it is already clear that this approach will have an impact on the renewal of the conceptual, analytical and programmatic framework of CRISES, not only by clarifying and refining it but also by expanding its analytical potential. The methodology, rendered available to researchers outside CRISES, will also potentially impact social innovation research at a larger scale. For example, the conceptual thesaurus, being (to the authors' knowledge) the first extensive repertoire of concepts on social innovation, will be available as a reference to be used - criticised 
and extended - in new case studies and in other database projects. The utilisation of CRISES' relational database model will also permit research teams in other regions to populate their own databases in a similar fashion, enabling cross-territorial comparison.

The database also has limitations that must be taken into account. The first concerns the source of the data. The case studies were conducted according to analytical frameworks that, although sharing a common basis, often varied from one research team to another or evolved over time (three to four data collection templates have been used in the various research programmes at CRISES over time). As indicated earlier, the conceptual model of the database reflected the many meanings and notions associated with the nature of social innovation (such as 'new governance') as well as the evolution of the overall analytical framework (e.g., the economic 'crisis' of the 1980s was experienced at the time as economic recession and institutional reforms but is interpreted today as a global phenomenon). A second limitation concerns the fact that the data, largely based on interviews and organisational document analysis, had already been filtered and codified by researchers. In other words, the database on social innovations is populated with 'real world' data that has been selected and filtered on the basis of a specific research objective. This systematic data analysis reveals the subtle evolution of the CRISES research programme since its creation in the 1980s. That said, the CRISES research programme has led to the development of a set of analytical tools that enable social innovation to be studied in a variety of ways (manufacturing companies, social economy, public policy networks, etc.).

In addition, the majority of case studies developed by CRISES were based on non-probabilistic sampling of social innovations. Essentially, the cases were composed of a series of non-random samples based on criteria that varied depending on the research programme. Hence, serious caution needs to be taken in the interpretation of the data, considering the sample and coding biases inherent to this methodology (see Biernaki, 2012). Given this limitation, care must be taken in interpreting the comparative analyses, the results of which cannot be generalised to all social innovations produced in Québec (or indeed beyond Québec). However, this does not detract from the ability of comparative analyses to identify trends, which, as spatial, temporal or sector phenomena, could not be detected otherwise. The comparative analyses will enable typologies, possibly even models, to be built and tested with a hypothetical-deductive method. In this way, the generalisability of results is increased relative to the case study method. 


\section{Potential contributions: from micro to meso and macro}

The concept of social innovation has a variety of meanings, from new social relations, to solutions, to complex social and environmental problems (Nicholls and Murdoch, 2012). Research studies conducted by CRISES have been inspired by different approaches to social innovation that highlight organisational (Schumpeter, 1932), institutional (North, 1990; Scott, 1995) and governance-related (Enjolras, 2008) innovations, national systems (Freeman, 1991; Lundvall, 1992; Nelson, 1993) and innovation regimes (Nelson and Winter, 1982), as well as social entrepreneurs (Caulier-Grice et al., 2010; Young, 1983) and social enterprises (Defourny and Nyssens, 2013), in particular within social (Vienney, 1994) and solidarity-based (Laville, 1994) economies. Moreover, innovations are identified as social based on their purpose (responding to aspirations and to social, cultural territorial needs), their processes (new social relations, new combinations) and their reach (having been taken up within institutions). Lastly, studies conducted by CRISES on social innovations are correlated to development paths or paradigms. In other words, social innovation is conceived of with the view towards social transformation (Klein et al., 2013).

The link between social innovation and social change or social transformation is explained either as a pattern of dissemination and growth supported by inter-organisational relations (e.g., Dees et al., 2004; Mulgan et al., 2007) or by the capacity to connect to societal challenges and dynamics (Howaldt and Schwarz, 2010), suggesting new institutional frameworks or development paradigms (Klein, Laville and Moulaert, 2014). New methods for researching social innovation are needed to explore how social innovation and transformation are related, leading to strengthening the theoretical foundation of social innovation. CRISES' approach proposes that social innovations and social transformations take shape along three dimensions - method of organisation, institutional form and social relationships - and that within these dimensions, the three levels of analysis, macro, micro and meso, are correlated. The macro level pertains to social structures and regulations; micro to social agency, identity rationales and action; and meso to organisations and networks.

These three dimensions are usually analysed in a contingent manner, with social innovation (micro or meso) being driven by social movements in times of crisis (macro) in a given territorial, sectoral and historical context (meso or macro). The CRISES case studies have, indeed, been conducted mainly at the local level on organisations that 
implement innovations. According to Tardif (2005, p. 25), the approach is based on the notion of the emergence of social innovation:

As a localized process initiated by different actors who seek to change the interactions taking place between themselves as well as with their organizational and institutional environment - the whole with the aim to counteract the impact of crises while attempting to reconcile the different levels of individual interest, public interest and common good.

The statistical analysis of data will make it possible to move from a micro to a meso and macro approach to studying social innovation. The assumption is that there are objects of study of relevance for social innovation that are not observable at the micro scale. At the meso level of analysis, such a database will allow for a new reading of social innovations in terms of the mechanisms, configurations, evolution and modes of dissemination in time and across locations and sectors of activity. The approach will, moreover, make it possible to focus on phenomena hitherto little studied in the Québec context, such as the emergence and dissemination of innovation clusters, including their patterns and paths of institutionalisation or even their configuration into an innovation system, and to examine their impacts on social transformation, in particular with regard to the Québec development model. This framework, once applied to Québec, may be extended to other areas in order to conduct international comparisons.

There are, indeed, times and territories where social innovations tend to multiply, taking the form of innovation clusters, especially at the onset of crises or in economies with plural tendencies (Klein et al., 2013). Innovations are, then, oriented along emerging socio-technical paradigms, such as new representations of problems and possible solutions or experiments that were successfully carried out in organisations and local communities. For example, during the 1980s and 1990s in Québec, when the crisis of Fordism and the welfare state became apparent, social innovations arose in the areas of labour, people services, collective enterprises, public policies and local development (the areas that CRISES focuses on). Using the CRISES Database on Social Innovations, it will be possible to trace the dynamics of the emergence of these innovations as well as their spread into clusters and their wider impacts on society. For example, a researcher might study the proximity effect, which is a phenomenon that promotes collective dynamics with the potential to modulate or reject the dominant forms of social control or 
even to propose innovative institutional solutions for a given organisation, industry or territory (Gilly and Pecqueur, 1995).

Using the database it will be possible to study the processes leading to the institutionalisation of social innovations. These issues have been addressed through various approaches, including institutionalist and neo-institutionalist theories, theories of regulation as well as economic sociology inspired by theories of conventions and social movements (Lévesque et al., 2001). The idea of an innovation system draws from the institutionalist approach to building national and regional innovation systems (see Lundvall, 1992). The neo-institutionalist approach places emphasis on the effects of dependencies that limit institutional changes (path dependency), explaining institutionalisation as adaptation and diffusion (Nelson and Winter, 1982; 2002; Schumpeter, 1932; Porter, 1990). However, the notion of path-building, that refers to the ability of collective actors to break up the regulatory framework in order to create a new one, can complement the notion of dependency. Pathbuilding also reveals how social innovations can serve as tools for social transformation (Klein et al., 2013, p. 382; Fontan et al., 2008). Theories of regulation, for their part, have insisted on the deterministic relation between institutions and innovations at the organisational level, albeit characterising institutions as historical and political organisations that result from contingent conflicts between social actors (Aglietta, 1998; Boyer, 1986). The theories on social movements have taken into account the effects of institutions on collective mobilisation and conflict. Among these are the political opportunity structure (McAdam, 1982), the repertoire of collective action (Tilly, 1976; 1986), the agency of social actors and actionalist approaches (Touraine, 1997; Mellucci, 1985) and the resource mobilisation theory (McCarthy and Zald, 1973). Finally, theories on conventions have studied the dynamics of building compromises that lead to the institutionalisation of innovations (Boltanski and Chiapello, 1999; Boltanski and Thévenot, 1991). These theoretical approaches, thereby, offer a variety of explanations of the institutionalisation process of social innovations, ranging from adaptation to institutional constraints, changes in the face of conflict dynamics, to the compromises between actors on the basis of conventions. The statistical analysis of a large amount of data will reveal patterns in the processes of institutionalising innovations and the relationships between these patterns and different governance regimes.

Finally, at the macro-analytical level, the relations between social innovation and the Québec development model can be examined. Often referred to as an 'innovation system', the Québec model is characterised 
by partnership governance, civil society's participation in the design and implementation of public policies, and the establishment of a plural, mixed, economy (Klein et al., 2013). This analysis would lead to a more in-depth understanding of the characteristics of this model, including its evolution over time, as well as the effects of social innovations on social transformation. Social innovation could even be examined with regard to its possible capacity to influence or transform the development model itself (Lipietz, 1989), and conversely, the effects of such a modified model on social innovation. It would also be possible to study regional innovation systems in the context of smaller territories or sector-based innovation systems (Lévesque, 2011).

There are many other possible lines of research that could be addressed by the CRISES Database on Social Innovation, including:

- To what extent does the state-institutional framework (public policy, governance schemes, etc.) influence the means - collective action and social innovations - used by organisations to respond to civil society's needs and aspirations? An answer to this question might be found in the analysis, for a given territorial context, of the relationships between the legal and regulatory framework in which organisations operate; the public policies and government programmes that apply to organisations; and the factors of emergence of social innovations, in particular the needs and aspirations leading to collective action.

- How does geographic proximity influence the development of social innovation clusters and which sectors of activity are the most conducive to the development of such clusters?

- To what extent do the different types of interactions between organisations have an influence on the development of certain types of social innovation? This pertains to the question of networking between organisations, and a network analysis calls for a spatiotemporal analysis of data. More concretely, the composition and structure of networks, as manifested in interactions, can be studied by means of visualisations and associated analytical methods. In fact, graphs are the most widely used theoretical tool for modelling and identification of properties of structured sets (Beauquier et al., 1992). They are essential to anyone wishing to study and represent a set of links between elements of a finite set of objects (Xuong, 1992). In the CRISES Database on Social Innovations, a detailed analysis of networks of organisations will be realised on the basis of spatiotemporal measurements of the density, eccentricity and centrality of 
these networks. The characteristics of organisations and interactions (relations) will serve as discriminating factors for providing a better understanding of certain types of social innovations.

Thus, by expanding the level of analysis and by allowing for comparative analyses, the database can strengthen and build the existing links between social innovation and social transformation. In this way, it will allow for a thorough examination of a central assumption of CRISES, namely that room for innovation and experimentation widens when the macro-social regulations (market, state, collective agreements) are in flux. In such a context, micro-systems can serve as places from which to identify the processes in which new social patterns emerge. By building clusters (Schumpeter, 1932; Porter, 1990) and by institutionalising along different logics, they can form systems and eventually shape new national trajectories of growth (Hollingsworth and Boyer, 1997; Strange, 1996; Crouch and Streeck, 1996).

\section{Conclusion}

The decision to develop a database on social innovation was prompted by the limitations of the case study method in terms of the systematisation and generalisation of the knowledge produced on social innovation at the micro-analytical level. In particular this concerned the local emergence of innovations within organisations.

At the methodological level, the purpose of building the relational database was to allow the transformation of qualitative data on social innovation into quantifiable data in one information system, in order to facilitate the structuring and management of a large volume of data and the creation of multiple data sets. The systematic and formal organisation of data allows for rigorous multidimensional and comparative statistical analyses and, therefore, enhances the generalisability of results. The implementation of such an approach at CRISES calls for a more in-depth conceptual examination, if not a re-conceptualisation, of social innovation in order to expand the scope of study to new objects. The transition to a meso-level of analysis would allow social innovation phenomena to be studied that are in the process of emerging or spreading, particularly in the form of clusters, alongside their institutionalisation in the context of differentiated governance regimes. Finally, the expansion of analysis to the macro-level would make it possible to explore social innovation systems, be they regional, sectoral or national and, thereby, the impact of innovations on the social transformations of the Québec model of development. 
To conclude, three epistemological issues raised by the development of the CRISES Database on Social Innovations should be mentioned. These relate to the nature, validity and interpretation of data. The case studies included in the database so far are mainly based on qualitative research methods that take into account the (inter)subjective interpretation of the phenomena under study (Anadón and Guillemette, 2007). This is reflected in the dominance of interviews as a way of learning about the point of view of key actors. To deal with this issue, the proposed database is designed to allow for a transition to a quantitative analysis of data, namely by reducing and formalising the information. Yet, how can it be ensured that their intended meaning does not get lost in the process? On the other hand, the creation of a database of case studies raises the question of the triple interpretation of data: that of the interviewees who provided the information to the researchers conducting the case studies; that of the researchers who collected, organised, analysed and published the data; and the interpretation of the team of researchers who re-conceptualised and organised the information from the case studies for the creation of the database. Given these multiple interpretations, what reading can be given of the results of the comparative analyses generated by the database? Finally, faced with these multiple levels of interpretation, how can the codification of normative evaluations be prevented, in other words, those comprising value judgments rather than facts?

Nonetheless, the case studies all have a common focus: social innovation. Moreover, the three to four data collection templates used in the various research programmes at CRISES through time share many common concepts and dimensions of analysis. The case studies concerned observations that were relatively limited in time (thirty years) and space (Québec). A number of contextual (institutional, demographic, sociopolitical, etc.) variables are, therefore, common to many of them. In short, the many case studies produced by CRISES constitute a source of knowledge and information that has been underutilised to date. Aside from representing a unique opportunity for research of its kind, the project to create a relational database requires formalising a conceptual framework of social innovation to advance the theoretical analysis underlying its work.

To create a quantitative approach and a relational database is a novel way to research social innovation. It is a new way of gathering data in order to develop theories about the generation, emergence and life cycle of social innovations. Should other researchers in the world opt for a similar conceptual framework and relational database model, 
international comparison would be possible; this would represent a completely innovative way to research social innovation.

\section{Acknowledgements}

We wish to acknowledge the especially valuable contribution of David Longtin, who wrote the first draft of this chapter resulting from a collaborative research process. We thank the reviewers for their constructive comments on an earlier version of this text.

\section{Notes}

1. Examples include the Welfare Innovations at the Local Level in Favour of Cohesion (WILCO) and TRANsformative Social Innovation Theory (TRANSIT) projects, both of which make extensive use of case studies. See http://sire search.eu/social-innovation/research-projects [Accessed 23 September 2014].

2. Idiographic studies aim at understanding what is a particular activity or individual, in a given context and at a given moment, whereas nomographic studies aim to establish general causal laws of phenomena (Smith, Harré and Langenhove, 1995).

3. The work of formalisation must comply with the main methodological principles, which are the relevance and the operationalisation principle (Flory and Laforest, 2005; Meier, 2006).

4. CRISES bases its work about social innovation on social movement theories, institutionalism theories (French regulation school, convention economy and sociology) and organisation theories. See Bouchard and Lévesque, 2013.

\section{References}

Aglietta (1998) Accumulation et crises du capitalisme, Paris: Odile Jacob (First edition 1976).

Anadón, M. and Guillemette, F. (2007) 'La recherche qualitative est-elle nécessairement inductive?', Recherches qualitatives, 5: 26-37.

Beauquier, D., Berstel, J. and Chrétienne, P. (1992) Éléments d'algorithmique. Paris: Masson.

Bélanger, P.R. and Lévesque, B. (1992) 'La théorie de la régulation, du rapport salarial au rapport de consommation. Un point de vue sociologique', Cahiers de recherche sociologique, 17: 17-51.

Bernier, L., Bouchard, M.J. and Lévesque, B. (2002) 'La prise en compte de l'intérêt général au Québec. Nouvelle articulation entre l'intérêt individuel, collectif et général', in Enjolras, B. and von Bergmann-Winberg, M.-L. (eds), Plural Economy and Socio-Economic Regulation - Économie plurielle et régulation socio-économique. Brussels: CIRIEC-International.

Biernaki, R. (2012) Reinventing Evidence in Social Enquiry: Decoding Facts and Variables. New York: Palgrave Macmillan.

Boltanski, L. and Chiapello, E. (1999) Le nouvel esprit du capitalisme. Paris: Gallimard. 
Boltanski, L. and Thévenot, L. (1991) De la justification: Les économies de la grandeur. Paris: Gallimard.

Bouchard, C. (1999) Contribution à une politique de l'immatériel. Recherche en sciences humaines et sociales et innovations sociales. Québec: Conseil québécois de la recherche sociale, Groupe de travail sur l'innovation sociale.

Bouchard, M.J. and Lévesque, B. (2013) 'L'innovation et les transformations sociales, une approche théorique plurielle de l'économie sociale. Le cas du Québec', in Hiez, D. et Lavillunière, E. (eds), Théorie générale de l'économie sociale et solidaire. Luxembourg: Larcier.

Boyer, R. (1986) Théorie de la régulation. Une analyse critique. Paris: La Découverte. Caulier-Grice, J., Kahn, L., Mulgan, G., Pulford, L. and Vasconcelos, D. (2010) Study on Social Innovation. London: Young Foundation, Social Innovation eXchange (SIX) and Bureau of European Policy Advisors.

Comeau, Y., Boucher, J.L., Malo, M.-C. and Vaillancourt Y. (2001) Essai de typologie des entreprises de l'économie sociale et solidaire. Montréal: Cahiers du CRISES, no. ET0117.

Cornforth, C. (2004) 'The Governance of Cooperatives and Mutual Associations: A Paradox Perspective', Annals of Public and Cooperative Economics, 75: 11-32.

Crouch, C. and Streeck W. (1996) Political Economy of Modern Capitalism: Mapping Convergence and Diversity. London: Sage.

Dees, J.G., Battle Anderson, B. and Wei-Skillern, J. (2004) 'Scaling Social Impact', Stanford Social Innovation Review, Spring 2004: 1-4.

Defourny, J. and Nyssens, M. (2013) 'Social Innovation, Social Economy, Social Enterprise: What Can the European Debate Tell Us?', in Moulaert, F., MacCallum, D., Mehmood, A. and Amdouch, A. (eds), The International Handbook on Social Innovation. Collective Action, Social Learning and Transdisciplinary Research. Cheltenham, UK and Northampton, MA: Edward Elgar.

Enjolras, B. (2008) Gouvernance et intérêt général dans les services sociaux et de santé. Brussels: P.I.E. Peter Lang.

Favreau, L. (1995) Repenser le mouvement communautaire dans une perspective d'économie solidaire. Une hypothèse de renouvellement de la problématique et de la politique du développement communautaire et de l'économie sociale au Québec. Montréal: Cahiers du CRISES, no. ET9505.

Favreau, L. and Lévesque B. (1995) Repenser le développement communautaire et l'économie sociale à la faveur de la crise de l'emploi et de la crise de l'État-providence. Montréal: Cahiers du CRISES, no. ES9504.

Flory, A. and Laforest, F. (2005) Les bases de données relationnelles. Paris: Economica. Fontan, J.-M., Klein, J.-L. and Tremblay, D.-G. (2008) 'Social Innovation at the Territorial Level: From Path Dependency to Path Building', in Drewe, P., Klein, J.-L. and Hulsbergen, E. (eds), The Challenge of Social Innovation in Urban Revitalization. Amsterdam: Techne Press.

Freeman, C. (1991) 'Innovation, Changes of Techno-Economic Paradigm and Biological Analogies in Economics', Revue Economique, 42 (2): 211-32.

Gilly, J.-P. and Pecqueur, B. (1995) 'La dimension locale de la régulation', in Boyer, R. and Saillard, Y. (eds), Théorie de la régulation - l'état des savoirs. Paris: La Découverte.

Hodgson, D.E. and Briand, L. (2013) 'Controlling the Uncontrollable: Project Management and Illusions of Autonomy in Video Game Development', Work, Employment and Society, 27 (2): 308-25. 
Hollingsworth, J.R. and Boyer, R. (1997) Contemporary Capitalism: The Embeddedness of Institutions. Cambridge: Cambridge University Press.

Howaldt, J. and Schwarz, M. (2010) Social Innovation: Concepts, Research Fields and International Trends. Dortmund (Germany), International monitoring (IMO). See http://www.internationalmonitoring.com/research/trend_studies/ social_innovation.html [Accessed 11 September 2013].

Klein, J.-L. and Champagne, C. (eds) (2011) Initiatives locales et lutte contre la pauvreté et l'exclusion. Québec: Presses de l'Université du Québec. Collection Innovation sociale.

Klein, J.-L., Fontan, J.-M., Harrisson, D. and Lévesque B. (2013) 'The Québec Model: A Social Innovation System Founded on Cooperation and Consensus Building', in Moulaert, F., MacCallum, D., Mehmood, A. and Amdouch, A. (eds), The International Handbook on Social Innovation. Collective Action, Social Learning and Transdisciplinary Research. Cheltenham, UK, and Northampton, MA: Edward Elgar.

Klein, J.-L. and Laville, J.-L. (with the collaboration of Moulaert, F.) (2014) 'Repères introductifs', in Klein, J.-L., Laville, J.-L. and Moulaert, F. (eds), L'innovation sociale. Paris: Érès.

Lapointe, P.-A. (2000a) Participation et démocratie au travail. Montréal: Cahiers du CRISES, no. ET0014.

Lapointe, P.-A. (2000b) Partenariat, avec ou sans démocratie. Montréal: Cahiers du CRISES, no. ET0015.

Laville, J.-L. (ed.) (1994) L'économie solidaire, une perspective internationale. Paris: Desclée de Brouwer.

Lévesque, B. (2011) Innovations sociales et pouvoirs publics: Vers un système québécois d'innovation dédié à l'économie sociale et solidaire. Quelques éléments de problématique. Montréal: Cahiers du CRISES, no. ET1106.

Lévesque, B., Bourque, G. and Forgues, E. (2001) La nouvelle sociologie économique. Originalité et tendances nouvelles. Paris: Desclée de Brouwer.

Lipietz, A. (1989) Choisir l'audace. Une alternative pour le XXIe siècle. Paris: Éditions la Découverte.

Lundvall, B.-A. (ed.) (1992) National Systems of Innovation. Toward a Theory of Innovation and Interactive Learning. London and New York: Anthem Press.

Mata-Toledo, R.A. and Cushman, P.K. (2002) Introduction aux bases de données relationnelles. Paris: Dunod.

McAdam, D. (1982) Political Process and the Development of Black Insurgency. Chicago, IL: University of Chicago Press.

McCarthy, J.D. and Zald, M. (1973) The Trend of Social Movements in America: Professionalization and Resource Mobilization. Morristown, NJ: General Learning Press.

Meier, A. (2006) Introduction pratique aux bases de données relationnelles (Deuxième édition). Paris: Springer-Verlag France.

Melucci, A. (1985) 'The Symbolic Challenge of Contemporary Movements', Social Research, 52 (4): 789-816.

Mulgan, G., Tucker, S., Ali, R. and Sanders, B. (2007) Social Innovation: What It Is, Why It Matters and How It Can Be Accelerated. Oxford: Skoll Centre for Social Entrepreneurship.

Nelson, R. (1993) National Innovation Systems. A Comparative Analysis. Oxford: Oxford University Press. 
Nelson, R. and Winter, S. (1982) An Evolutionary Theory of Economic Change. Cambridge, MA: Harvard University Press.

Nelson, R. and Winter, S. (2002) 'Evolutionary Theorizing in Economics', Journal of Economic Perspectives, 16 (2): 23-46.

Nicholls, A. and Murdock, A. (2012) Social Innovation: Blurring Boundaries to Reconfigure Markets. Basingstoke: Palgrave Macmillan.

North, D.C. (1990) Institutions, Institutional Change and Economic Performance. Cambridge: Cambridge University Press.

Porter, M.E. (1990) The Competitive Advantage of Nations. New York: The Free Press. Schumpeter, J.-A. (1932) 'Entwicklung' (with translation into English 'Development'), http://www.schumpeter.info/ [Accessed 3 November 2014].

Scott, W.R. (1995) Institutions and organizations. Thousand Oaks, CA: Sage.

Sinton, D.F. (1978) 'The Inherent Structure of Information As a Constraint to Analysis: Mapped Thematic Data As a Case Study', in Dutton, G. (ed.), Harvard Papers on Geographic Information Systems. Reading, MA: Addison-Wesley.

Smith, J.A., Harré, R. and Van Langenhove, L. (1995) 'Idiography and the Case Study', in Smith, J.A., Harré, R. and Van Langenhove, L. (eds), Rethinking Psychology. London: Sage.

Strange, S. (1996) 'L'avenir du capitalisme mondial. La diversité peut-elle persister indéfiniment?' in Crouch, C. and Streeck, W. (eds), Les capitalismes en Europe. Paris: La Découverte.

Tardif, C. (2005) Complémentarité, convergence et transversalité: La conceptualisation de l'innovation sociale du CRISES. Montréal: Cahiers du CRISES, no. ET0513.

Tilly, C. (1976) From Mobilization to Revolution. Reading, MA: Addison-Wesley.

Tilly, C. (1986) The Contentious French. Cambridge, MA: Harvard University Press. Touraine, A. (1997) Le retour de l'acteur. Essai de sociologie. Paris: Librairie générale française.

Vienney, C. (1994) L'économie sociale. Paris: La Découverte.

White, D., Mercier, C., Dorvil, H. and Juteau, L. (1992) 'Les pratiques de concertation en santé mentale: Trois modèles', Nouvelles Pratiques Sociales, 5 (1): 77-93. Xuong, N.H. (1992) Mathématiques discrètes et informatique. Paris: Masson.

Yin, R.K. (1994) Case Study Research. Design and Methods. Thousand Oaks, CA: Sage. Young, D.R. (1983) If Not for Profit, for What? Lexington, MA: D. C. Heath and Company.

Except where otherwise noted, this work is licensed under a Creative Commons Attribution 3.0 Unported License. To view a copy of this license, visit http://creativecommons.org/licenses/by/3.0/ 